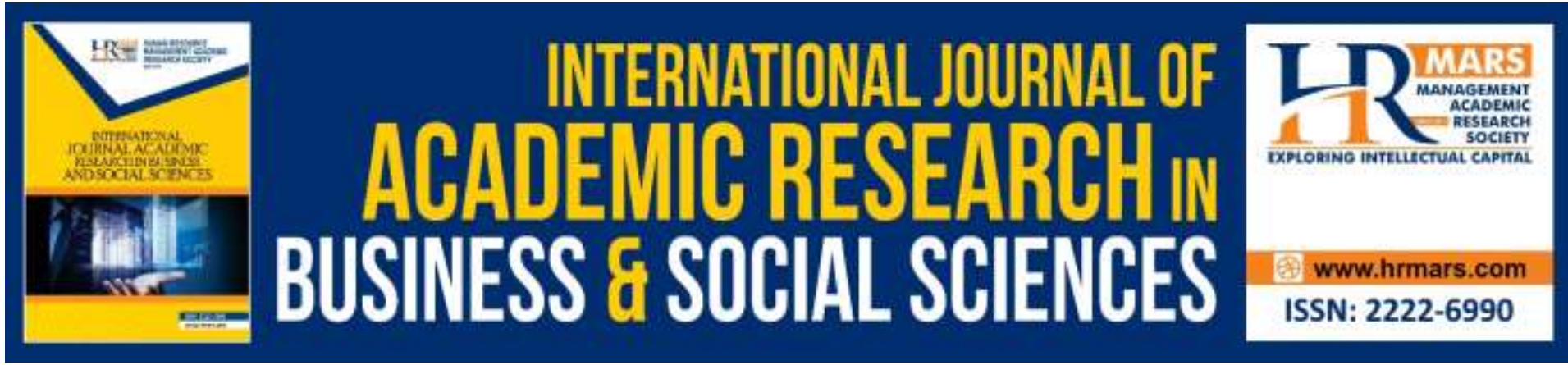

\title{
A Framework for Continuous Improvement Process Capability and Knowledge Absorptive Capacity towards Military Logistics Performance: A Dynamic Capability Perspective
}

Chong Kim Loy, Abdul Rahim Abdul Rahman, Saharudin Abd. Rashid, Noor Raihan Ab. Hamid

To Link this Article: http://dx.doi.org/10.6007/IJARBSS/v9-i7/6399

DOI: $10.6007 /$ IJARBSS/v9-i7/6399

Received: 16 May 2019, Revised: 19 June 2019, Accepted: 28 June 2019

Published Online: 24 July 2019

In-Text Citation: (Loy, Rahman, Rashid, \& Hamid, 2019)

To Cite this Article: Loy, C. K., Rahman, A. R. A., Rashid, S. A., \& Hamid, N. R. A. (2019). A Framework for Continuous Improvement Process Capability and Knowledge Absorptive Capacity towards Military Logistics Performance: A Dynamic Capability Perspective. International Journal of Academic Research in Business and Social Sciences, 9(7), 1321-1336.

Copyright: (C) 2019 The Author(s)

Published by Human Resource Management Academic Research Society (www.hrmars.com) This article is published under the Creative Commons Attribution (CC BY 4.0) license. Anyone may reproduce, distribute, translate and create derivative works of this article (for both commercial and non-commercial purposes), subject to full attribution to the original publication and authors. The full terms of this license may be seen at: http://creativecommons.org/licences/by/4.0/legalcode

Vol. 9, No. 7, 2019, Pg. 1321-1336 


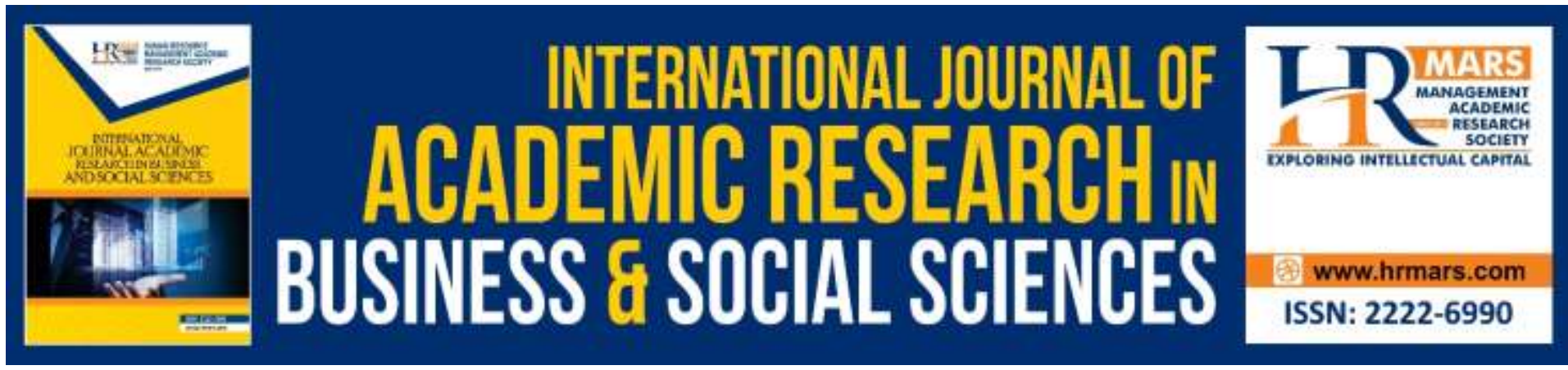

\title{
A Framework for Continuous Improvement Process Capability and Knowledge Absorptive Capacity towards Military Logistics Performance: A Dynamic Capability Perspective
}

\author{
Chong Kim Loy, Abdul Rahim Abdul Rahman, Saharudin Abd. \\ Rashid, Noor Raihan Ab. Hamid \\ Faculty of Business Technology \& Accounting, UNITAR International University, Malaysia
}

\begin{abstract}
This paper discusses the benchmarking, flexible and innovation process as continuous improvement business processes that drive organizational performance of logistics service providers in the military system. From dynamic capability theory perspectives, the organizational dynamic capability of each military logistics service providers may impact the military as the end users. With emphasize on the proposed business processes towards logistics performance, knowledge absorptive capacity is an additional factor that moderates the relationship between continuous improvement and logistics performance. This paper would give insights through proposed research framework using dynamic capability theory as theoretical stance as well as providing logistics service providers with business framework that impacted on logistics performance with knowledge absorptive capacity as enhancers to the military logistics operation in the military.
\end{abstract}

Keywords: Dynamic Capability, Continuous Improvement Process Capability, Knowledge Absorptive Capacity, Military Logistics Operation Performance, Military Logistics Performance

\section{Introduction}

In the present exceptionally complex world, organizations need to continuously adjust to new circumstances if they are to endure and flourish continuous improvement strategy. The present pattern is toward, among others, innovation-based upgrade of centre processes and compelling management of resources through came about to productive resource and asset management. One of the basic processes of an organization is logistics and supply chain. Logistics and supply chain management (L\&SCM) has been raised to key level whereby organizations can accomplish differentiation while maintaining low cost of operation. The expanding complexities of modern global logistics and supply chain, along these lines call for skilled and knowledgeable workforce who is equipped to execute and deal with the processes requires knowledge absorptive capacity. In a military setting, logistics department is viewed as the columns and spine of its operations. Thus, the military should take thoroughness 
measures to cultivate the adequacy of its logistics initiative and its knowledgeable workforce and proficiency of its continuously improving its organization that advantages the organization.

In global present-day warfare, the accomplishment of Desert Storm Operation was vigorously relied upon the Desert Shield Operation that moved heaps of logistics supports to Saudi Arabia from United States (Pogonis \& Cruikshank, 1992). As indicated by Pogonis and Cruikshank (1992), the basic accomplishment to the Second Gulf War (2 ${ }^{\text {nd }}$ of August 1990-28 $8^{\text {th }}$ February 1991) was because of fantastic military logistics operation practices. During the Operations Desert Shield and Desert Storm, logistics authorities confronted undefeatable difficulties, which somewhat have provoked them to locate another way and reconfigure the logistics processes to guarantee the organization of 350,000 battle troops, hardware and supplies into the war zone. Not just that, the logistics leadership need to continuously supply sustenance, water, fuel, ointments, ammo and spare parts as required if the war endured to over long land separation. With restricted assets and enormous topographical separation, the race to convey the provisions and send the battle troops into the war zone, alongside the standard haze and contact of operations required preoccupation from the current operations requires powerful military logistics operation management as equivalent to business logistics (Yoho, 2013).

\section{Dynamic Capability Theory}

Dynamic capability alludes to scholarly examples of aggregate action and strategic schedules through which an organization could create and adjust working practices to accomplish new design (Teece, 2007). As per the theory, strategic decision-making and partnership management alongside the inside authoritative assets help guarantee that substantive capacities are arranged to give competitive advantage. The theory helps in comprehension of how an organization could acquire, deploy and reconfigure resources as well as processes. The theory has gotten reliable help experimentally in logistics management literature. For instance, Jin and Edmunds (2015) has conceived a conceptual framework researching the job of assets in improving supply chain capacities, while Beske (2012) show knowledge and business processes as supply chain dynamic abilities that would encourage in accomplishing firm performance. Regardless of these literary works, little examination anyway exists to clarify the issues with regards to military organizations.

In the current economic circumstances, it is broadly acknowledged that organizations including military units are regularly looked with absence of assets, compelling them to work under extreme money related requirements (Zucchella \& Siano, 2014). Besides, inadequate assets can frequently guide organizations to concentrate on short-term rather than long-term goals, dishearten them from further investigation, improvement and abuse of chances existing in environment. Subsequently, the DCT point of view proves to be useful as it offers a chance to break down the logistics performance that is related with interior assets and capacities. Past literatures (Jansen, Tempelaar, Bosch \& Volberda, 2009; Kamasak, Yavuz \& Altuntas, 2016) has highlights ecological dynamism as the rate of change, unpredictability and instability in external environment. In an exceptionally dynamic condition, organizations may face difficulties in reacting to the clients' requests and investigating new options. However, on a similar time, a dynamic domain may likewise compel organizations to reinforce their 
existing capabilities and grow new ones to empower them to contend. On the off chance that a situation is seen to be dubious, organizations may utilize their existing knowledge repositories more effectively and enhance their capabilities through learning capabilities.

For instance, Ramamurti (2012) and Uner, Kocak, Cavusgil and Cavusgil (2013) found that the accomplishment of developing business sector organizations did not exude from their minimal effort advantages, yet through their aptitudes of screening the market's needs. Subsequently, it is normal that military organizations may use and upgrade their capacities to beat explicit competitive difficulties in a dynamic circumstance. In the military dynamism, the logistics specialist organizations for the unit may confront challenges to connect with and continue their logistics performance because of the issues, for example, operational gridlock and innovation outdated nature. Henceforth, they must improve their dynamic capability to guarantee logistics performance. Nonetheless, dynamism in military setting are unique thus needs different follow through depending in the context of the military organization to operate successfully in changing military environment (Rahman \& Hamid, 2019). On that note, military operations speak about operational vulnerability, which require tremendous logistics and supply chain support. This would require the logistics units to reconfigure their processes of benchmarking, flexibility and innovation to satisfy the operational need and market request (Tavani, Sharifi, \& Ismail, 2013). To prepare, plan and perform well in the battle operations, it is important to comprehend the dynamic capability theory and its effect on logistics performance and logistics capabilities.

Extant literatures looks into the empirical evidence researches (O'Shannassy, 2008; Kamasak et al., 2016; Patel et al., 2012) feature that while very unsure condition may diminish the organizations' capacity to react to the environmental changes and thus by investigating new circumstances, this sort of condition can likewise may reinforce their current abilities or grow new process, empowering them to beat their organizational inertia. For instance, so as to address difficulties in dynamic situations, organizations may put resources into benchmarking process, which would assist them with searching for the best practice and encourages authoritative figuring out how to accomplish higher performance (Shang and Marlow, 2005). Correspondingly, organizations that work in a dynamic domain would dynamically reconfigure processes to use their assets for better performance (Wei, Yi \& Guo, 2014).

\section{Military Logistics Operation}

Military logistics operations incorporate the process of supplying spare parts, supporting just as conveying and repatriating weapon frameworks (Simon, 2001). Contrasts from business logistics services, military logistics envelops all exercises expected to empower the conveyed military to continuously keep up its preparation to achieve mission. Military logistics was resulting from the necessities of war and the requirements to move and move troops, gear and supplies to the war zone (Glass, Hoffman \& Ebig, 2012). As indicated by the Yost (2010), North Atlantic Treaty Organization (NATO) is developing in defence sourcing (Davids, Beeres, \& Fenema, 2013) and in addition military logistics not just arrangements with transporting, picking, storing and maintaining the weapon systems, it also encompasses the construction and operation of facilities and medical as well as health service support. In military, logistics 
effectiveness gives off an impression of being the most pivotal components adding to the military achievement.

An effective logistics operation will encourage in expanding the battling intensity of a military organization as warriors required weapons, however sustenance and ammo to do their obligations well. This is especially significant when military units' adventure away from their very own outskirts, as they would confront more noteworthy troubles in getting supplies. Inefficient logistics operations in military would in the long run lead to flimsier battle power and powerlessness to execute operations. Subsequently, it is no doubt that logistics service providers play a key role in a military organization. Military logisticians must almost certainly keep up the competitiveness in uncertain operational condition. In spite of the significance of logistics work in a military organization, accomplishing logistics effectiveness is troublesome and challenging.

Hence, for the most part, amid noteworthy deficiencies of the defence expenses, proficiency is significant (Markoff, Sanger \& Shanker, 2010). The improvement on capability and readiness can't be increment continually on account of constraints in assets and this requires the military to embrace continuous improvement strategy, for example, flexible process in their logistic operational routines. With restricted financial resources and resource constraints, accomplishing and keeping up logistics performance in military gives off an impression of being very challenging yet knowledge can ease them (Mogos, Descotes \& Walliser, 2013). Considering this circumstance, the military organization has grasped not on focusing on adjusting modernization assets but also maintaining in developing its human capital advancement. On a comparative note, the necessity of the nation's military in continuous improvement technique like development process practice over its progressive system makes a requirement for innovation and creative process to achieve reliable and superior workforce. In examining the two needs, development process is required (Huber, 1991). In another report on benchmarking process on logistics operation routine, there are mandates, for example, one of the training and doctrine of a military organization objective is to refresh its present Military Standard Operating Procedure (MSOP) in light of progress in current condition dynamism. The shortcomings featured are essential to positive advance to improve its performance of time and cost of military logistics operations (Rutner et al., 2012).

Logistics management is known to be the center capacity of any military powers (Tzu, 1983; Ballou, 2007; Rutner, 2012) and it is compulsory to keep logistics work force furnished with current competencies in the field. The military environment represents the harsh reality as it has put essentially in the faculty preparing for a mind-blowing expectation to support logistically any military operation. By the by, the abundance of logistics strategic knowledge might be lost when they leave toward the finish of their military professions (Mclntyre et al., 2003). Zahra and George (2002) audit knowledge absorptive capacity (Cohen \& Levintan, 1990) with consideration of four measurements, which are knowledge acquisition, knowledge assimilation, knowledge transformation and knowledge exploitation. Since 1940's the military has persevered through various sizes of internal and external conflicts and threats. The encounters got during these occurrences are contended to improve and build up the logistics capabilities of military in battle status in engrossing essential knowledge in geographical distance (Szulanski, 1996; Koschatzky, 2002) and uncertain environment. 
The thought of retaining the present military condition requires a knowledge management process that knowledge absorptive capacity in nature moderate just as to upward the logistics performance of the military. Consistently there are quantities of military logisticians leaving the military due to maximum retirement length of service. Thus, this phenomenon requires the new workforce to retain and re-animate in confronting the external environment that may threat the national sovereignty, with the goal that the military knowledge stay applicable and maintaining a strategic distance from causal vagueness of which best practice that help logistics performance in current military logistics circumstance, so that, is not expendable. In the availability towards future workforce, external to internal knowledge on continuous improvement methodology, decrease system and logistics performance as dynamic knowledge required to oversee and hold the organization performance just as to close the causal ambiguity for best logistics performance, so that, the current military workforce are competent in dealing with the logistics operations proficiently though with resource constraints.

\section{Continuous Improvement Process Capability}

In this examination, continuous improvement methodology alludes to logistics operational processes that are precise and organized way to deal with investigate and persistently improve central organization' exercises with the point of improving the logistics services (Lee \& Dale, 1998). It is expected to adjust the processes to the organization's strategic objectives and internal clients' needs. This examination looks at the process capability as far as benchmarking and process adaptability as methodologies in dealing with the logistics operations to guarantee better readiness in process proficiency (Swink \& Schoenherr, 2015). Benchmarking has risen as an inexorably prevalent tool used to increase competitive advantage. It fills in as an examination and data get-together process that empowers a director to contrast one's organizational work performance and the others. In a military setting, benchmarking is significant since this would help army in deciding the capacities of its adversary. The monstrous research on benchmarking has been reported in the logistics management literature (Taschner \& Taschner, 2016; Su \& Ke, 2017).

With regards to this investigation, continuous improvement methodology in this examination adjusted two of three of Ding, Kam, and Lalwani (2012) operational routines constructs. The two constructs adjusted is benchmarking and flexible process. Benchmarking process is vital for maintainable (Bowersox \& Closs, 1996; Trkman, 2009) that additionally emphatically identified with performance (MSUGLRT, 1995; Stank \& Lackey, 1997; Shang \& Sun, 2004; Shang \& Marlow, 2005, 2007); at that point, flexibility process of which in clients need so as to have competitive edge (Zhang et al., 2005; Qureshi et al., 2008) that are likewise decidedly identified with performance. In a fierce domain, where numerous organizations face expanding request assortment and vulnerability, flexible processes are turning into a perpetually wanted capability (Van der Aalst, 2013). A flexible process is accepted to prompt performance (Barad \& Sapir, 2003), since it empowers organizations to redesign existing processes or make new ones to adapt to the dynamic condition (Raschke, 2010; Sharifi, Ismail, Qiu \& Tavani, 2013).

Inside the setting of military scene, logistics units with flexible process would probably proactively oversee requests from officers and upgrade the abilities of the military in combat 
readiness. A flexible logistics process, for instance, may permit moving of provisions and transportation among various units. A pull-based logistics system is a key wellspring of flexible processes, since it responds to genuine client requests, as opposed to push-based logistics system (Chopra \& Meindl, 2001). Likewise, it is normal that with flexible process, military logisticians can manage inside and outside changes adequately, bringing about logistics performance. To lessen the vulnerability condition, an organization needs a flexible process to be ideal in time and cost (Swafford, Ghosh \& Murthy, 2006).

Continuous improvement process is additionally connected with innovation process (Humphreys, McAdam \& Leckey, 2005; Hyland, Soosay \& Sloan, 2003). There are contrasts among item and innovations process (Cunliffe, 2008, Murat Ar \& Baki, 2011). An item innovation is the presentation of an item or administration that is new or broadly improved. This incorporates noteworthy improvements in specialized determinations, segments and materials, consolidated software, ease of use or other practical attributes (OECD, 2005). Unexpectedly a process innovation is the advancements in the generation process and the way products or services are created, including gear, work techniques, materials and work frameworks. The real improvement for process innovation is the cost viability (Cunliffe, 2008). In assembling industry, process innovations is decrease in process time prompting higher profitability and productivity, decrease in set-up time or potentially cost giving adaptability and upgrading the capability to deliver more assortment, improvements on the nature of yield, in this manner creating prevalent item and decrease of wastage, increment on process yield and along these lines improvement on conformance quality and product unwavering quality (Tirupati, 2008).

In the military, the top management is committed towards improving the capability of its organization through innovation and creative process initiated by its very own military innovation process. Past investigations demonstrated the significance of resources and competencies as key factors in understanding continuous innovation (Verona, 1999). In addition, dynamic capacities have dominatingly been the focal point of hypothetical discussion yet there is rising exact proof on the processes and abilities that are basic to supported innovation (Garavan \& Carbery, 2013). With process innovation, it ensures sustainable development of that firm.

Nonetheless, there are just a couple of concentrates on logistics in concept of innovation (Flint et al., 2005; Soosay \& Hyland, 2004; Wagner, 2008). Along these lines, this investigation received the idea of process innovation however logistics investigate that disregarded the idea of innovation (Flint et al., 2005). With expanding pace and intricacy of conditions, the significance of innovation barely needs accentuation. As indicated by Subramaniam and Youndt (2005), innovation involves recognizing apparatuses, thoughts and chances to make new or improved products or services. However, an organization may have considerable hindrances in actualizing change or improving because of the absence of knowledge (PérezBustamante, 1999). Consequently, it is expected to cross over any barrier to improve the standard processes occasionally. Earlier research (Andriopoulos \& Lewis, 2010) recommends that as we live in time of "creative age", an organization's most profitable assets are its creative human capital who powers the innovation endeavors. 


\section{Knowledge Absorptive Capacity}

Knowledge absorptive capacity started from absorptive capacity. Absorptive capacity alludes to an organization's capacity to distinguish value, assimilate and apply new external information and apply it to commercial ends (Cohen and Levinthal, 1990). It doesn't just connect with organization's immediate interface, yet in addition the capacity to abuse the earth. Absorptive capacity has been found to accelerate organizational learning in international venturing (Zahra \& Hayton, 2008); technology sourcing (Ouyang, 2008; HaroDomínguez, Arias-Aranda, Lloréns-Montes \& Moreno, 2007), and strategic alliance (Muscio, 2007; Garcia-Morales, Lloréns-Montes \& Verdú-Joveret, 2007). In the context of this research, the knowledge absorptive capacity is expected to transform military units into a hybrid organization (Jay, 2013), which is not only focusing on obtaining efficiency for day to day operation but display creative and innovative initiatives. The operation of logistics and supply chain requires concentrated knowledge management process in absorptive capacity that prevailing in logistics operations requires such capability (Patel et al., 2012).

This sort of dynamic capability will empower organizations to abuse the elusive resources in a dynamic domain. With absorptive capacity, an organization can get, absorb, change and use knowledge (Patel, Terjesen and Li, 2012; Lawson \& Potter, 2012; Gutiérrez, Bustinza \& Molina, 2012, Scott, 2015) just as has strategy in utilizing or reacting (Vogus \& Sutcliffe, 2012; Ray, Baker \& Plowman, 2011; Scott, 2015). Through Patel et al. (2012), absorptive capacity in supply chain is operationalized and isolated into four elements of knowledge acquisition, knowledge assimilation, knowledge transformation and knowledge exploitation.

On the off chance that a situation is seen to be dubious, organizations may utilize their current knowledge repositories more effectively and improve their abilities through absorptive capacity. For instance, Ramamurti (2012) and Uner, Kocak, Cavusgil and Cavusgil (2013) found that the achievement of developing business sector organizations did not radiate from their ease advantages, yet through their abilities of screening the market's needs. Henceforth, it is normal that military organizations may use and improve their abilities to defeat explicit competitive difficulties in a questionable situation. In the current military condition, the service providers for the unit may confront challenges to draw in and support their logistics performance because of the issues, for example, resource constraints and limitation of budget.

Henceforth, they must upgrade their dynamic capability in connection to knowledge-based dynamics to guarantee logistics performance. To some degree, somewhat reminiscence of the past shared military operations experience, proved that, it requires colossal logistics and supply chain support. This would require the logistics units to reconfigure their processes of benchmarking, flexibility and innovation process as continuous improvement to put military as the force of choice. To prepare, get ready and perform well in the battle operations, it is important to comprehend the earth and its effect on performance and logistics capabilities through absorptive capacity. Therefore, with dynamics innovation processes in that capacity with regard to military capability and economic transformation (Nelson \& Winter, 1982) in commercial logistics, organizations create new knowledge (Nelson, 1995; Dosi, 1997; Metcalfe, 1998). This knowledge-based initiative is also in accordance to OEDC (2006). With the immerse initiatives, this may compensate the building dynamism (Fisher, 1997), which is 
pace of progress which is hard to anticipate (Dess and Beard, 1984) if not balance with knowledge-based initiative. Briefly, a supply chains may experience dynamism, which incorporates unstable or stable interest (Fisher, 1997). On that note, innovation and knowledge-based efforts towards dynamism among business and military logistics remain on a similar balancing effort that express innovation-based knowledge is the vital dynamism for key transformation strategies in military logistics performance.

\section{Military Logistics Performance}

Military logistics performance denotes parallel with the commercial logistics performance. It is defined, as the capacity to reliably convey requested products inside the requested conveyance period at an adequate expense, is very significant in accomplishing in general performance (Stank, Goldsby, Vickery \& Savitskie 2003). In the military, productive logistics, performance gives off an impression of being the most vital elements adding to the military achievement. An effective logistics operation will encourage in expanding the fighting power of a military organization as soldiers not only needed weapons, but also food and ammunition to carry out their duties well. In an undeniably testing condition, which is reflected by uncertain demands and rapid technology development, cost pressures remain high (Do \& Kambhampati, 2002). The logistics unit in the military has already been facing this challenge for years. Likewise, logistics effort in military setting must be substantially exploited to substantially achieve higher thus contribute and facilitate to extend of logistics 4.0 development towards agility and digitalization competency in such military setting (Rahman, Rashid \& Hamid, 2018). Therefore, military logistics performance can thusly be viewed as a legitimate logistics performance measure in military context.

The military organization is likewise confronting complexities attributable to the significant separation that the materials and supplies must navigate between the various hubs along the supply chain. In the military setting, it was customarily felt that having plenitude of provisions guaranteed that military logistics service providers would be able to provide everything needed to achieve the desired performance. Logistics performance in the military context is order fulfilment (Green et al., 2008) in both forward (Stank et al., 1999; Stank et al., 2001) and reverse logistics (Morgan et al., 2016). Both forward and reverse logistics needs to be integrated in the logistics management to attain an exceptional military logistics performance. Hence, consistently, logistics performance particularly at the the battlefield is essential for military organization.

\section{Methodology}

This study will employ explanatory and quantitative research method. The context of the study is explained through theory testing and proposition are developed based on literature review and context of the study. The proposition is also built based on literature review and context. Structural Equation Modelling (SEM) will be utilized as a primary data analysis technique. SEM will be used as it is capable to examine the entire model simultaneously and assessing measurement errors (Hair, Sarstedt, Hopkins \& Kuppelwieser, 2014). This study relies on variance-based SEM, using partial lease square (PLS). PLS has become one of the preferred data analysis techniques as it is suitable for small sample size (Hair et al., 2014). This technique is also increasingly used in various areas including logistics and supply chain management. Given this consideration, PLS therefore, serves as an appropriate data analysis 
tool for the proposed study. SEM based on the second order reflective constructs. The measures are that all indicators of measurement constructs are measured by the Likert Scale ranging from 1 "completely disagree" to 5 "completely agree".

Continuous Improvement Process Capability is a second-order reflective model consisting of three first-order constructs: benchmarking process, flexible process, and innovation process. Items are adopted from Shang and Marlow $(1997,2007)$, Ding et al. (2012) and Murat Ar and Baki (2011).

Knowledge Absorptive Capacity is a second-order reflective measurement model consisting of four first order constructs: knowledge acquisition, knowledge transformation, knowledge transformation and knowledge exploitation, the participation of the logistics players in the decision making, and compensation and rewarding. Items are adopted from Patel et al. (2012).

Military Logistics Performance is a second order reflective measurement model consisting of two indicators of forward logistics and reverse logistics adopted from Stank et al. (1999), Stank et al. (2012) and Morgan et al. (2016).

\section{Proposed Research Framework}

Based on theoretical stance and literature review, Figure $\mathbf{1}$ is the proposed research framework.

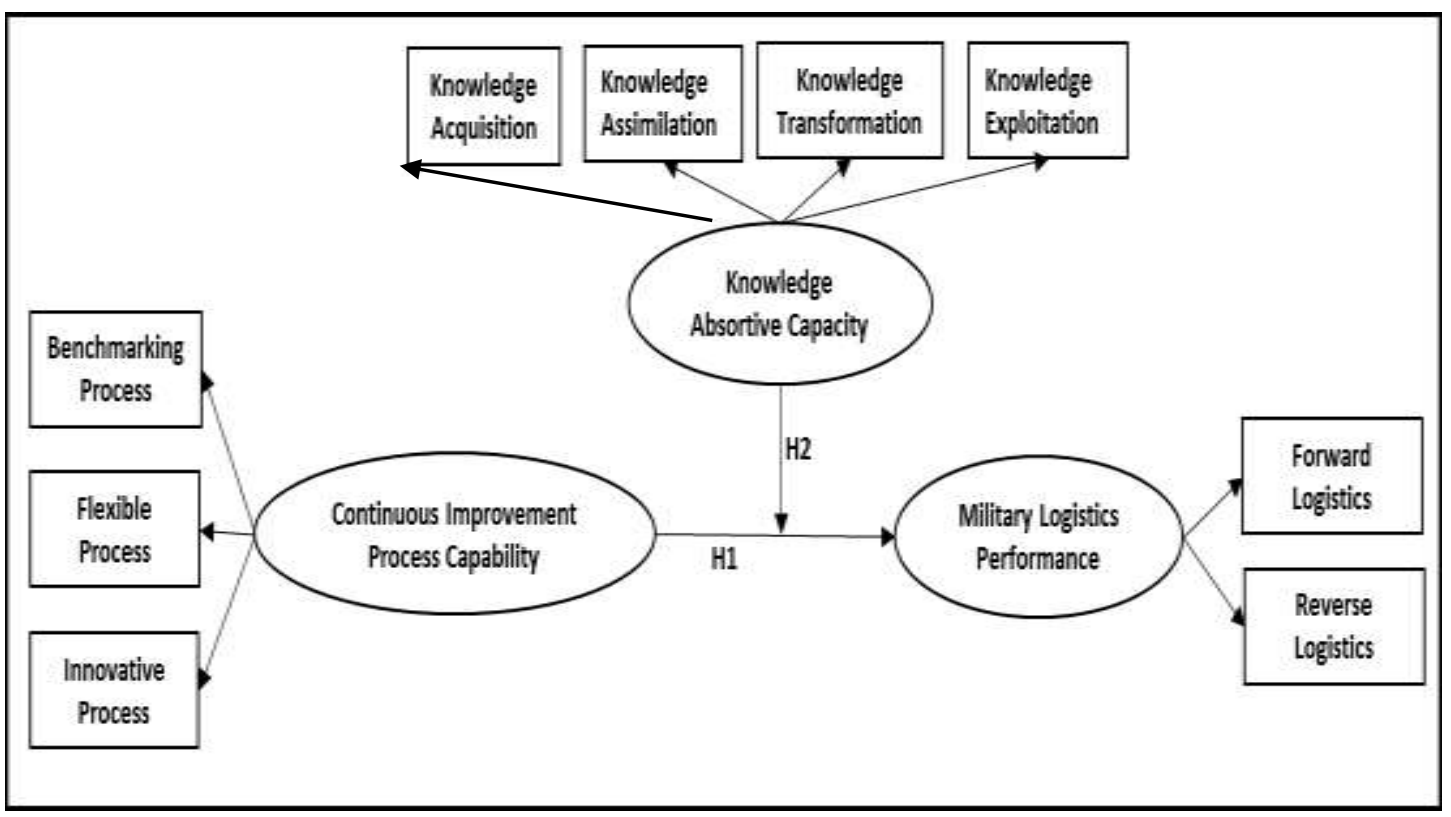

Figure 1: The Proposed Research Framework

In this study, continuous improvement strategy aims in improving the logistics services (Lee \& Dale, 1998). Benchmarking and flexibility process in logistics operations is to ensure better efficiency logistics operation (Swink \& Schoenherr, 2015). The immense research on benchmarking has been documented in the logistics management literature (Taschner \& Taschner, 2016; Su \& Ke, 2017). However, there are only a few studies on logistics in concept 
of innovation (Flint et al., 2005; Soosay and Hyland, 2004; Wagner, 2008). Thus, this study adopted the concept of process innovation though logistics research that overlooked the concept of innovation (Flint et al., 2005). According to Subramaniam and Youndt (2005), innovation entails identifying tools, ideas and opportunities to create new or improved products or services. Yet, an organization may have substantial barriers in implementing change or innovating due to the lack of knowledge. Hence, it is needed to bridge the gap to improve the routine processes from time to time. Prior research (Andriopoulos \& Lewis, 2010) suggests that as we live in time of "creative age", an organization's most valuable assets are its creative human capital who fuels the innovation efforts.

Prior works have documented that learning capability such as absorptive capacity can enhance an organization's process capabilities (Zahra \& George, 2002; Flatten, Engelen, Zahra \& Brettel, 2011). Organizations with high absorptive capacity for instance, could analyze and interpret information about changes in the environment and make necessary configuration and realignment of process capabilities (Souchon \& Diamantopoulos, 1997). In the logistics field, having a high absorptive capacity would facilitate them in being more efficient and effective in processing information (Julien \& Ramangalahy, 2003), and quickly adjust the mobility of logistics flexibility to uncertain environment (Lioa \& Tu, 2007). By contrast, organizations with restricted absorptive capacity are less likely to be able to respond well to the uncertain environmental owing to their limited capability to acquire and assimilate (Flatten, Greve \& Brettel, 2011; Descotes \& Walliser, 2013). Based on these arguments and based on the above research framework as Figure 1, two propositions are developed to explain the relationships between the variables. This study postulates that:

$\mathrm{H} 1$ : The positive relationships between continuous improvement process capability on the military logistics performance.

$\mathrm{H} 2$ : The positive relationships between continuous improvement process capability and the military logistics performance with the influence of knowledge absorptive capacity.

\section{Conclusion}

From a practical perspective, the findings of this study are expected to facilitate them military in formulating strategies and capitalizing on the internal capabilities which may provide platforms and opportunities for more effective logistics management. This is important considering that the performance of logistics function relies on numerous factors. Investigation of the factors that influence logistics performance has been a crucial to the military concern since logistics function is crucial to ensure long-term survival in dynamic and uncertain global environments. In an uncertain economic environment, the country's military requires capabilities to manage their static knowledge resources effectively due to financial constraints. This research will also inform the government on the feasibility of existing or future strategies, since aggressive intervention by the government is needed to develop the country's military logistics capacities and success.

The findings of this study also expected to contribute to the military logistics literature. This research offers understanding of how the military could improve their logistics performance by looking at the organizational processes' capabilities, dynamic environments and learning 
capabilities. Logistics management has been a crucial part of a military organization for decades. From the management perspective there is always concern related to the efficient and timely delivery of troops, equipment and supplies to the battlefield. In an uncertain environment, with restricted financial resources, the military needs to be able to innovate by finding new ways of attaining logistics efficiency. The delivery of efficient and effective military logistics services requires highly skilled managerial and operational staff. As highlighted by the military organization, embracing an alignment between asset modernization and human capital development may help the units in achieving performance. In response to this, this study brings together relevant literature streaming from logistics management and strategic management in examining how the military could enhance their logistics performance. Constructs such as knowledge absorptive capacity, continuous improvement process capability and military logistics performance are integrated in the general research framework of this study.

At the end, this study also attempts to contribute to a better understanding of logistics performance in a military landscape by identifying best practice by closing the causal ambiguity by using dynamic capability theory as a platform to achieve logistics performance. Since this study is also focusing on how knowledge management process of knowledge absorptive capacity plays its role in achieving logistics performance, then a more comprehensive conceptual framework is required based on dynamic capability theory which as the underpinning theory of this study. This research therefore is expected to fill the research gap by developing a new theoretical conceptual model through dynamic capability theory in military setting.

\section{Acknowledgement}

The researchers like to thanks the Faculty of Business Technology \& Accounting, UNITAR International University, Malaysia, military senior officers and academicians as well to those involved directly and indirectly that have helped in conducting this conceptual study.

\section{Corresponding Author}

Abdul Rahim Abdul Rahman, Faculty of Business Technology \& Accounting, UNITAR International University, Malaysia, Email: rahimov1999@gmail.com.

\section{References}

Andriopoulos, C., \& Lewis, M. W. (2010). Managing innovation paradoxes: Ambidexterity lessons from leading product design companies. Long range planning, 43(1), 104-122.

Barad, M., \& Sapir, D. E. (2003). Flexibility in logistic systems-modeling and performance evaluation. International Journal of Production Economics, 85(2), 155-170.

Beske, P. (2012). Dynamic capabilities and sustainable supply chain management. International Journal of Physical Distribution \& Logistics Management, 42(4), 372-387.

Chopra, S., \& Meindl, P. (2001). Supply chain management: strategy. Planning and Operation, 15(5), 71-85.

Cohen, W. M., \& Levinthal, D. A. (1990). Absorptive capacity: A new perspective on learning and innovation. Administrative science quarterly, 128-152. 
Davids, C., Beeres, R., \& van Fenema, P. C. (2013). Operational defense sourcing: organizing military logistics in Afghanistan. International Journal of Physical Distribution \& Logistics Management, 43(2), 116-133.

Ding, M. J., Kam, B. H., \& Lalwani, C. S. (2012). Operational routines and supply chain competencies of Chinese logistics service providers. The International Journal of Logistics Management, 23(3), 383-407.

Do, M. B., \& Kambhampati, S. (2002, April). Planning Graph-based Heuristics for Cost-sensitive Temporal Planning. In AIPS (pp. 3-12).

Dosi, G. (1997). Opportunities, incentives and the collective patterns of technological change. The economic journal, 107(444), 1530-1547.

F. Hair Jr, J., Sarstedt, M., Hopkins, L., \& G. Kuppelwieser, V. (2014). Partial least squares structural equation modeling (PLS-SEM) An emerging tool in business research. European Business Review, 26(2), 106-121.

Flatten, T. C., Engelen, A., Zahra, S. A., \& Brettel, M. (2011). A measure of absorptive capacity: Scale development and validation. European Management Journal, 29(2), 98-116.

Flatten, T. C., Greve, G. I., \& Brettel, M. (2011). Absorptive capacity and firm performance in SMEs: The mediating influence of strategic alliances. European Management Review, 8(3), 137-152.

García-Morales, V. J., Lloréns-Montes, F. J., \& Verdú-Jover, A. J. (2007). Influence of personal mastery on organizational performance through organizational learning and innovation in large firms and SMEs. Technovation, 27(9), 547-568.

Glas, A., Hofmann, E., \& Eßig, M. (2013). Performance-based logistics: a portfolio for contracting military supply. International Journal of Physical Distribution \& Logistics Management, 43(2), 97-115.

Gutiérrez, L. G., Bustinza, O. F., \& Molina, V. B. (2012). Six sigma, absorptive capacity and organizational learning orientation. International Journal of Production Research, 50(3), 661-675.

Huber, G. P. (1991). Organizational learning: The contributing processes and the literatures. Organization science, 2(1), 88-115.

Humphreys, P., McAdam, R., \& Leckey, J. (2005). Longitudinal evaluation of innovation implementation in SMEs. European Journal of Innovation Management, 8(3), 283-304.

Hyland, P. W., Soosay, C., \& Sloan, T. R. (2003). Continuous improvement and learning in the supply chain. International Journal of Physical Distribution \& Logistics Management, 33(4), 316-335.

Jansen, J. J., Tempelaar, M. P., Van den Bosch, F. A., \& Volberda, H. W. (2009). Structural differentiation and ambidexterity: The mediating role of integration mechanisms. Organization Science, 20(4), 797-811.

Jay, J. (2013). Navigating paradox as a mechanism of change and innovation in hybrid organizations. Academy of Management Journal, 56(1), 137-159.

Jin, Y., \& Edmunds, P. (2015). Achieving a competitive supply chain network for a manufacturer: a resource-based approach. Journal of Manufacturing Technology Management, 26(5), 744-762.

Julien, P. A., \& Ramangalahy, C. (2003). Competitive strategy and performance of exporting SMEs: An empirical investigation of the impact of their export information search and competencies. Entrepreneurship Theory and Practice, 27(3), 227-245. 
Kamasak, R., Yavuz, M., \& Altuntas, G. (2016). Is the relationship between innovation performance and knowledge management contingent on environmental dynamism and learning capability? Evidence from a turbulent market. Business Research, 9(2), 229-253.

Lawson, B., \& Potter, A. (2012). Determinants of knowledge transfer in inter-firm new product development projects. International Journal of Operations \& Production Management, 32(10), 1228-1247.

Lee, R. G., \& Dale, B. G. (1998). Business process management: a review and evaluation. Business process management journal, 4(3), 214-225.

Markoff, J., Sanger, D. E., \& Shanker, T. (2010). In digital combat, US finds no easy deterrent. The New York Times, 25.

Metcalfe, J. S. (1998). Evolutionary economics and creative destruction (Vol. 1). Psychology Press.

Michigan State University Global Logistics Research Team (MSUGLRT) (1995). World Class Logistics: The challenge of Managing Continuous Change, Council of Logistics Management, Oak Brook, IL.

Mogos, Descotes, R., \& Walliser, B. (2013). Foreign market-related knowledge absorption and the international financial performance of SMEs. Management international/International Management/Gestiòn Internacional, 17(4), 178-193.

Murat Ar, I., \& Baki, B. (2011). Antecedents and performance impacts of product versus process innovation: Empirical evidence from SMEs located in Turkish science and technology parks. European Journal of Innovation Management, 14(2), 172-206.

Muscio, A. (2007). The impact of absorptive capacity on SMEs' collaboration. Economics of Innovation and New Technology, 16(8), 653-668.

Najafi Tavani, S., Sharifi, H., \& S. Ismail, H. (2013). A study of contingency relationships between supplier involvement, absorptive capacity and agile product innovation. International Journal of Operations \& Production Management, 34(1), 65-92.

Nelson, R. R. (1995). Recent evolutionary theorizing about economic change. Journal of economic literature, 33(1), 48-90.

Nelson Richard, R., \& Winter Sidney, G. (1982). An evolutionary theory of economic change. Harvard Business School Press, Cambridge.

Organization for Economic Cooperation and Development (2005). Promoting Innovation and Services, Paris.

Organization for Economic Cooperation and Development (2006). The Knowledge Based Economy, Paris.

O'Shannassy, T. (2008). Sustainable competitive advantage or temporary competitive advantage: Improving understanding of an important strategy construct. Journal of Strategy and Management, 1(2), 168-180.

Ouyang, H. (2008). Resources, absorptive capacity, and technology sourcing. International Journal of Technology Management, 41(1-2), 183-202.

Patel, P. C., Terjesen, S., \& Li, D. (2012). Enhancing effects of manufacturing flexibility through operational absorptive capacity and operational ambidexterity. Journal of Operations Management, 30(3), 201-220.

Pérez-Bustamante, G. (1999). Knowledge management in agile innovative organizations. Journal of knowledge management, 3(1), 6-17. 
Pagonis, W. G., \& Cruikshank, J. L. (1992). Moving mountains: Lessons in leadership and logistics from the Gulf War. Harvard Business Press.

Rahman, A. R. A., \& Hamid, N. R. A. (2019). Achieving Logistics Performance in Military Environmental Dynamism: The Role of Organizational Capabilities. International Journal of Supply Chain Management, 8(2), 1004-1017.

Rahman, A. R. A., Rashid, S. A., \& Hamid, N. R. A. (2018). Agility and digitalization competency in logistics 4.0 in military setting: the challenge, risks and opportunities. Asian Journal of Social Science Research, 1(2).

Ramamurti, R. (2012). Competing with emerging market multinationals. Business Horizons, $55(3), 241-249$.

Raschke, R. L. (2010). Process-based view of agility: The value contribution of IT and the effects on process outcomes. International Journal of Accounting Information Systems, 11(4), 297-313.

Ray, J. L., Baker, L. T., \& Plowman, D. A. (2011). Organizational mindfulness in business schools. Academy of Management Learning \& Education, 10(2), 188-203.

Rutner, S. M., Aviles, M., \& Cox, S. (2012). Logistics evolution: a comparison of military and commercial logistics thought. The International Journal of Logistics Management, 23(1), 96-118.

Scott, N. D. (2015). Antecedents and Outcomes of Ambidexterity in the Supply Chain: Theoretical Development and Empirical Validation (Doctoral dissertation, University of Toledo).

Shang, K. C., \& Marlow, P. B. (2005). Logistics capability and performance in Taiwan's major manufacturing firms. Transportation Research Part E: Logistics and Transportation Review, 41(3), 217-234.

Sharifi, H., Ismail, H. S., Qiu, J., \& Tavani, S. N. (2013). Supply chain strategy and its impacts on product and market growth strategies: a case study of SMEs. International Journal of Production Economics, 145(1), 397-408.

Simon, S. J. (2001). The art of military logistics. Communications of the ACM, 44(6), 62-66.

Souchon, A. L., \& Diamantopoulos, A. (1997). Use and non-use of export information: Some preliminary insights into antecedents and impact on export performance. Journal of Marketing Management, 13(1-3), 135-151.

Su, S. I. I., \& Ke, J. Y. F. (2017). National Logistics Performance Benchmarking. Journal of Supply Chain and Operations Management, 15(1), 55.

Subramaniam, M., \& Youndt, M. A. (2005). The influence of intellectual capital on the types of innovative capabilities. Academy of Management journal, 48(3), 450-463.

Stank, T. P., \& Lackey Jr, C. W. (1997). Enhancing performance through logistical capabilities in Mexican maquiladora firms. Journal of business logistics, 18(1), 91.

Swafford, P. M., Ghosh, S., \& Murthy, N. (2006). The antecedents of supply chain agility of a firm: scale development and model testing. Journal of Operations Management, 24(2), 170-188.

Swink, M., \& Schoenherr, T. (2015). The Effects of Cross-Functional Integration on Profitability, Process Efficiency, and Asset Productivity. Journal of Business Logistics, 36(1), 69-87.

Taschner, A., \& Taschner, A. (2016). Improving SME logistics performance through benchmarking. Benchmarking: An International Journal, 23(7), 1780-1797. 
Teece, D. J. (2007). Explicating dynamic capabilities: the nature and microfoundations of (sustainable) enterprise performance. Strategic management journal, 28(13), 13191350.

Uner, M. M., Kocak, A., Cavusgil, E., \& Cavusgil, S. T. (2013). Do barriers to export vary for born globals and across stages of internationalization? An empirical inquiry in the emerging market of Turkey. International Business Review, 22(5), 800-813.

Wagner, S. M., Rau, C., \& Lindemann, E. (2010). Multiple informant methodology: a critical review and recommendations. Sociological Methods \& Research, 38(4), 582-618.

Wei, Z., Yi, Y., \& Guo, H. (2014). Organizational learning ambidexterity, strategic flexibility, and new product development. Journal of Product Innovation Management, 31(4), 832-847.

Van Der Aalst, W. M. (2013). Business process management: a comprehensive survey. ISRN Software Engineering, 2013.

Yoho, K. D., Rietjens, S., \& Tatham, P. (2013). Defence logistics: an important research field in need of researchers. International Journal of Physical Distribution \& Logistics Management, 43(2), 80-96.

Yost, D. S. (2010). NATO's evolving purposes and the next Strategic Concept. International affairs, 86(2), 489-522.

Zahra, S. A., \& Hayton, J. C. (2008). The effect of international venturing on firm performance: The moderating influence of absorptive capacity. Journal of Business Venturing, 23(2), 195-220.

Zahra, S. A., \& George, G. (2002). Absorptive capacity: A review, reconceptualization, and extension. Academy of management review, 27(2), 185-203.

Zucchella, A., \& Siano, A. (2014). Internationalization and innovation as resources for SME growth in foreign markets: a focus on textile and clothing firms in the Campania Region. International Studies of Management \& Organization, 44(1), 21-41. 